\section{masunusunum ANALISIS DE COYUNTURA}

Revista Venezolana de Análisis de Coyuntura ISSN: 1315-3617

coyuntura@cantv.net

Universidad Central de Venezuela Venezuela

Vera, Leonardo V.

A chronicle of a Latin American country financial crash: the case of Venezuela

Revista Venezolana de Análisis de Coyuntura, vol. VI, núm. 2, julio-diciembre, 2000, pp. 177-209

Universidad Central de Venezuela

Caracas, Venezuela

Available in: http://www.redalyc.org/articulo.oa?id=36460207

How to cite

Complete issue

- More information about this article

Journal's homepage in redalyc.org

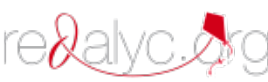

Scientific Information System Network of Scientific Journals from Latin America, the Caribbean, Spain and Portugal Non-profit academic project, developed under the open access initiative 


\title{
A CHRONICLE OF A LATIN AMERICAN COUNTRY FINANCIAL CRASH: THE CASE OF VENEZUELA
}

\author{
Leonardo V. Vera* \\ ESCUELA DE ECONOMíA, UCV
}

\begin{abstract}
:
Between 1994 and 1995 the Venezuelan banking experienced a drastic financial crash that eventually took half of the banking industry down, created a wave of bankruptcies of enterprises, distorted public finances (as government assistance to ailing banks mounted), and generated a balance of payments crisis. This paper details the events that precipitated Venezuela's financial crisis and examines how the problems took shape The paper outlines the factors that cause and precipitate a financial collapse. These are summarized in three broad categories, namely: the macroeconomic context, the institutional setting, and policy orientation. The Venezuelan experience demonstrates that the so-presumed coherence between orthodox reforms and financial liberalization should not be exaggerated. If the reforms itself generate transitory but severe macroeconomic instability and are implemented without taking care of a fragile institutional setting and an already dangerous trend in banking operations, the results can be counter-productive.
\end{abstract}

Key Words: Financial Crash, Latin America, Venezuela.

\section{INTRODUCTION}

During the last three decades a large number of Latin American countries, at all levels of development, have suffered the drastic consequences of a financial crash. In all cases financial reforms aimed at ending financial repression, as defined by the McKinnon-Shaw framework preceded a financial debacle. The economy of Venezuela joined this club in 1994-1995 when a financial crisis eventually took half of the banking industry down, created a wave of bankruptcies of enterprises, distorted public finances (as government assistance to ailing banks mounted), and generated a balance of payments crisis. Although the Venezuelan banking crisis does mirror other crisis in Latin America, the way the process took shape deserves close scrutiny. Importantly, the Venezuelan experience provides a clear and recent confirmation of the whole complex interplay of factors that cause and precipitate a financial collapse. We summarize these factors in three broad categories, namely: the macroeconomic context, the institutional setting, and policy orientation. This distinction allows us to detect neatly similar trends in other developing countries.

* Assistant Professor, Central University of Venezuela, Escuela de Economía, Caracas 1050, Venezuela. 
The distinction also proved to be particular appropriate to separate the underlying institutional and macroeconomic conditions that led the financial system toward a fragile position (the underlying causes), from the actions taken to guide decision making (the precipitating factors). These latter factors seem to be important since historical events indicate that the apt use of economic policy may mitigate signals of serious weaknesses in the financial structures. Unfortunately, both orthodox development economists and multilateral institutions have exerted an increasing influence toward orthodox economic reforms including financial deregulation, when the experience in Latin America seems to indicate that the countries where these reforms were implemented most religiously often had to deal with bank failures and economic disarray ${ }^{1}$.

This article details the events that precipitated Venezuela's financial crisis and examines how the problems took shape. Although Venezuela's banking crisis is closely related to the intervention and control of the country's second-largest bank, its foundations were laid much earlier. Section B briefly documents the development strategy followed during the 1970s and the changing events of the 1980s. Specifically, we emphasize the way the banking industry fit and adapted to the events. Section $C$ schematically presents the liberalization attempt. Section $D, E$ and $F$ examine the possible underlying causes of the financial collapse, taking special consideration of the macroeconomic factors, the institutional setting, and the resulting trends in the banking system. Section $G$ discusses and evaluates the impact of the policy reforms undertaken in 1989 and their subsequent development. Section $\mathrm{H}$ describes the financial collapse and the costs of the crisis. A final section summarizes the argument.

\section{FROM THE GOLDEN AGE TO STAGFLATION}

The most striking feature of the Venezuelan economy between 1960 and 1980 was its remarkably rapid growth and its low inflation path. During this period the rate of growth of output averaged 4.4 percent and the average rate of inflation was 5.9 percent. This relatively good macroeconomic performance has been attributed to the stable economic and political international context that governed the world economy between the sixties and the mid seventies. The Venezuelan economy was allowed to seek a regime of fixed exchange rates, fixed interest rates and fiscal balance that marked the overall financial and business environment (Hausmann 1990). In addition, the favorable trend of the price of crude oil, the sharp increase in

\footnotetext{
${ }^{1}$ We refer here to the cases of Argentina, Uruguay and Chile in the southern cone, to the cases of Colombia and Paraguay in the rest of South America, and Costa Rica and Mexico in Central America.
} 
the quantity of oil exports and especially the oil boom of 1973-1974 enabled Venezuela to embark upon a massive development process, which placed a strong emphasis on infrastructure (especially construction) and heavy industry. As the increased oil revenue accrued largely to the government, a rapid expansion of public sector expenditures occurred between 1974 and 1982. This relatively good period of prosperity fostered the development of the financial system and the profusion of new banking activities. Since the early 1960s, financial deepening as measured by the M2/GNP ratio and the number of offices and agencies per capita increased significantly until the mid 1980s (see figure 1). Figure 2 also shows how the deposits/GDP and credit/GDP ratios grew markedly since the late 1960s until 1988 (when the trend reverses). Similarly, the level of real assets showed signs of expansion until 1988 when the inflationary floor started to rise (see figure 3). What it is quite remarkable is that the financial system was able to sustain its development relatively well in spite of financial repression, lack of foreign competition and strong public sector intervention in financial activities ${ }^{2}$.

Fig. 1. Financial Sector: Evolution of the M2/GDP Ratio and the Proportion of Population per Office



Source: Central Bank of Venezuela and Banking Association.

\footnotetext{
${ }^{2}$ Until the late 1980s, Venezuela was a classic case of financial repression. Not only did the government maintained interest rates ceilings on bank assets and liabilities and dictated lending quotas to what it deemed high-priority sectors, but it created an important development banking system. Moreover, since 1970 banking legislation prohibited the expansion of foreign banks by limiting their size to a maximum of 20 percent of the capital of the whole banking system, by limiting the number of offices and agencies in the national territory and by prohibiting the reception of government funds. The partial reform of banking legislation in 1975 virtually eliminated the presence of foreign banks in the country.
} 
Fig. 2. Commercial Banks: Evolution of the Deposits/GDP Ratio and the Loans/GDP Ratio

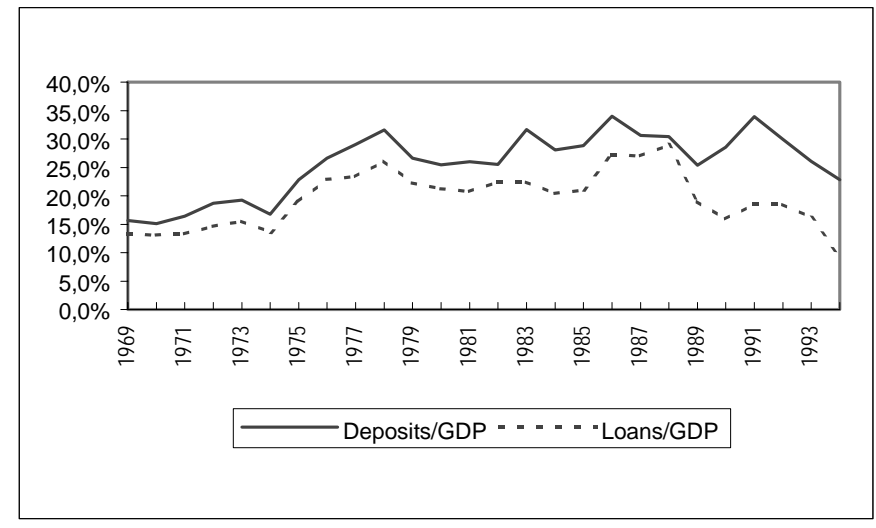

Source: Data from the Banking Superintendency.

Fig.3. Commercial Banks: Evolution of Real Assets

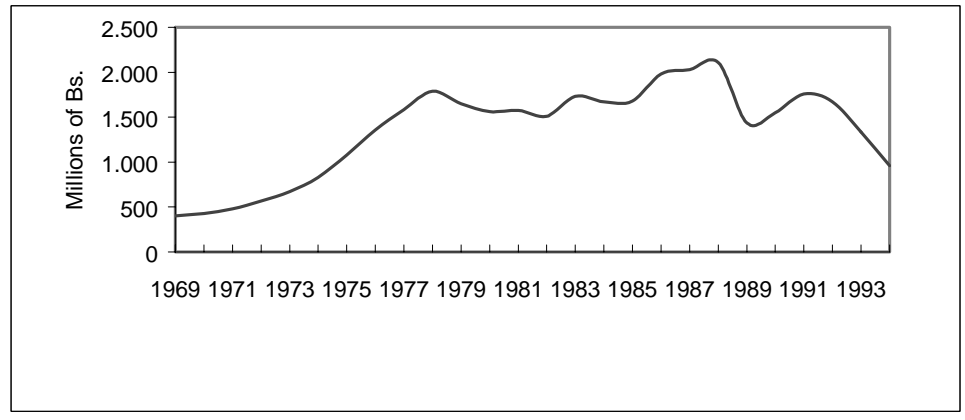

Source: Data from the Banking Superintendency

The 1973-1974 oil shock and the massive flow of resources transferred to the public sector largely drove the operations of the private banking system (which at the time was basically composed of commercial and mortgage banks). Fiscal expansion helped banking operations in three ways: (a) it helped increased the formation of deposits in commercial banks; (b) it increased lending operations by channeling funds through second tier financial institutions; and (c) it expanded the scale of public investment projects which required the added participation of local and foreign banks. Between 1978 and 1982 the ratio of checking account deposits and other short-term and long-term bank deposits to M2 (which measured the 
proportion of money held in the banking system) averaged 0.9 , a figure that met developed-country standards.

A softening of the world oil market in 1977-1978 contributed to the stagnation of fiscal revenues just in a moment in which public sector enterprises development projects expanded. Fiscal austerity fell upon government transfers to state enterprises and as a consequence a massive flow of external borrowing emerged as a counterpart. Increased oil exports in 1979-1980 turned the situation around, but only temporarily because exports revenues declined rapidly in 1981 and 1982 . Capital flight accelerated sharply when the price of oil began to decline and domestic residents started to anticipate a devaluation. The difficulties were magnified when the flow of international lending was suddenly interrupted by the end of 1982 and interest rates in international markets started to rise. Surprisingly, the growing disarray in the economy slightly affected the banking industry. Deposits/GDP and Credits/GDP ratios decreased in 1978 and stagnate until 1982, however, the overall performance of the banking system was not worse due to the way the banking system fit and adapted to the events. First, increased competition among domestic banks led gradually to the creation of financial groups, and this, in turn, increased bank's ability to keep or attract funds and generate profits ${ }^{3}$. Second, the freeing of interest rates on bank assets and liabilities in 1981 allowed the banks to increase the spread between bank's interest rates on loans and their cost of funds ${ }^{4}$. Finally, after the implementation of a multiple exchange rate system in 1983 banks found important sources of profitability in foreign exchange operations where trading and arbitrage opportunities promised substantial gains.

Several years of chaotic adjustment followed the change of the exchange rate regime in 1983. A severe fiscal adjustment and import compression led to output contraction during $1984-1985^{5}$. In 1985 three financial institutions were intervened and a commercial bank (Banco de Comercio) liquidated. Severe deficiencies in banking supervision were apparent when government authorities found out that these institutions loaned money to themselves or their affiliates, and that many short-term loans had no collateral backing ${ }^{6}$. Surprisingly, instead of enhancing regulatory capabilities, the government decided to create a nation's deposit

\footnotetext{
${ }^{3} \mathrm{~A}$ financial group usually consisted of a commercial bank, a mortgage bank, a financial society, a liquid assets fund, a leasing company and an insurance company.

${ }^{4}$ In 1984 ceilings on interest rates paid on deposits and for loans were re-established, priorities lending quotas to agriculture were increased to $22.5 \%$ and preferential interest rates were reintroduced for agriculture and construction activities.

${ }^{5}$ The output growth rates were -1.4 percent in 1984 and 0.2 percent in 1985 .

${ }^{6}$ As Haumann and Gavin (1995) have pointed out, in less florid times the lack of liquidity does not mask risky borrowers anymore who would be recognized from what they are.
} 
insurance authority (FOGADE) in $1985^{7}$. When strong fiscal expansion was pursued in 1986, the dramatic fall in world prices of crude oil led to a sharp deterioration of government finances, to a new exchange rate adjustment and higher inflation ${ }^{8}$. By the end of 1988 the macroeconomic imbalances were unsustainable. The Central Government deficit ballooned to 6.1 percent of GDP, the current account deficit reached \$5,809 million, the exchange rate remained clearly overvalued, demonetization was severe and international reserves almost exhausted. Against this economic background the incoming government of President Pérez implemented a mayor reform package under the tutelage and support of the IMF and the World Bank.

\section{ORTHODOX REFORMS AND FINANCIAL LIBERALIZATION}

The 1989 economic program was based on the standard IMF/World Bank menu of macroeconomic stabilization combined with the implementation of deep structural reforms. A shock treatment approach to adjustment was employed and largely justified by government officials in terms of taking advantage of the political momentum created by recent elections and the lack of capacity to monitor a gradual approach. The program had several targets: a restoration of balance of payments equilibrium and the orderly servicing of the foreign debt, control of inflation, and the creation of a structure of relative prices conductive to an efficient allocation of resources and growth. Tight monetary and fiscal policy, price liberalization of basic goods and an abrupt exchange rate adjustment were undertaken rapidly ${ }^{9}$. Basic policy reforms in the areas of foreign trade, privatization and domestic financial markets followed.

In the case of the financial sector, it should be pointed out that the core reforms included interest rates liberalization, the elimination of priority lending quotas, privatization of commercial banks under ownership of the Central Bank, and relaxation regarding the participation of foreign banks in the domestic financial market ${ }^{10}$. The strengthening of the supervisory institutions, the restructuring of public banks and funds and the reform of the legislation framework were set among

\footnotetext{
${ }^{7} \mathrm{~A}$ significant moral hazard problem can arise when the government reacts as Venezuelan authorities did in that occasion. Market discipline is difficult to establish if both banks and depositors implicitly assumed that the government is going to guarantee bank liabilities.

${ }^{8}$ Inflation increased from $11.6 \%$ in 1986 to $28.1 \%$ in 1987 and $29 \%$ in 1988.

${ }^{9}$ In March 1989, the domestic currency was devaluated by almost $100 \%$.

${ }^{10}$ Although the reserve requirements for the agricultural sector were eliminated, a preferential treatment was kept regarding interest rates. Interest rates ceilings were impose for agriculture activities below the market lending rate.
} 
the main targets of a sector loan approved and co-financed by the World Bank and the Inter-American Development Bank in 1990.

Unfortunately, as we will argue later, financial liberalization provided a fatal blow to the banking system and the real economy since it was implemented at a time of severe macroeconomic instability, deep recession, fragile institutional setting and an already dangerous trend in banking operations. Moreover, the so-presumed coherence of orthodox reforms should not be exaggerated. The pursuing of tight monetary policy, during a period of financial liberalization, with the effect of disrupting the real and financial sector, is a good example of how conflicts might arise between different aspects of the reforms programs.

Concerns about the consequences of financial liberalization have raised with the explosion of banking crisis around the globe in the last two decades. There is a widespread agreement that financial liberalization in the midst of macroinstability greatly exacerbates any economic dislocation (McKinnon 1993). Under conditions of instability (or some future threat), financial liberalization boost the level of interest rates, leading to disintermediation and causing problems of credit stringency for medium size and small firms. Moreover, where regulation, supervision and other parts of the infrastructure that support incentive-compatible behavior are absent, premature liberalization plays a role in the development of financial crisis (Stiglitz 1998). Though macroeconomic factors and institutional failure are common factors in bank insolvency in Latin America, premature liberalization could be cited in virtually all cases of financial crisis in the region. A recent study by Demirguc-Kunt and Detragiache (1998) test the hypothesis that financial liberalization increases the probability of a crisis for 53 industrial and developing countries (covering 19801995) and their findings are clear: Financial liberalization has an independent and negative effect on banking sector stability.

Based on the elements just mentioned above (the macroeconomic context, the institutional setting, and policy orientation) we will argue that a close evaluation of the explanatory circumstances surrounding the banking crisis and the course of action chosen to guide decision making after 1989, may help provide a good understanding on how the banking crisis of 1994 took shape.

\section{THE MACROECONOMIC ENVIRONMENT}

There are two related aspects of macroeconomic environment that can have major impacts on financial performance. The first concerns macroeconomic stability, which often manifest itself through the behavior of domestic prices and the performance of the external sector. The second aspect concerns global 
failure and the ensuing collapse of effective demand and economic activity (the downturn of 1993 is a prime example of such event). We will deal briefly with each of these aspects.

A key necessary (but not sufficient) prerequisite for the liberalization of the financial markets and the growth of financial intermediation is a stable macroeconomic environment. In general, reforms have to take place after macroeconomic stabilization has been achieved ${ }^{11}$. Basically, interest rates should be liberalized and financial markets deregulated after inflation, the budget deficit and external shocks are stabilized. None of these conditions existed when the reform process and the strategy to liberate Venezuelan financial markets gathered momentum. The fundamental point is that the conjunction of these macroeconomic maladies may increase the vulnerability of the financial system.

As an emerging literature has emphasized the key role of uncertainty in investment decisions follows directly from the irreversible nature of most investment expenditures (see Bernanke 1983, and Pindyck 1991). As a consequence, when irreversibility exists changes in uncertainty may postpone investment decisions and can have a very strong impact on the demand for credit. A high degree of uncertainty about the economic conditions that determine the future returns of investment has prevailed in the Venezuelan economy since the early 1980s. The economy has suffer, for instance, from high and unpredictable inflation, which has been usually matched by high relative price variability and important fluctuations in the terms of trade. Inflation variability was higher in the 1980s than in the 1970s and increased dramatically since 1989 (see figure 4).

The pattern of instability in the terms of trade over time also deserves some comments. Hausmann and Gavin (1996) have argued that a deterioration in the terms of trade or and adverse external shock may increase the number of nonperforming loans. The reason is that borrower profitability is affected by these events and this in turn deteriorates the quality of bank assets. As it is clear from figure 5, the Venezuelan economy has experienced recurrent shocks in its terms of trade as a consequence of fluctuations in oil prices. Taken from peak to peak

\footnotetext{
${ }^{11}$ Even orthodox revisionists of the financial liberalization position have now recognized that the traditional liberalization prescription needs to take account and pay careful attention to the broader macroeconomic environment (see for instance McKinnon, 1989). While this literature put too much stress on the role that macroeconomic stability has on credibility, we emphasize the channel through which instability affects the confidence and profitability of financial units.
} 
the fluctuations are short but nonperiodic, making decisions risky and affecting the saving-investment dynamics.

Fig.4. Venezuela: Inflation Rate and Inflation Variability

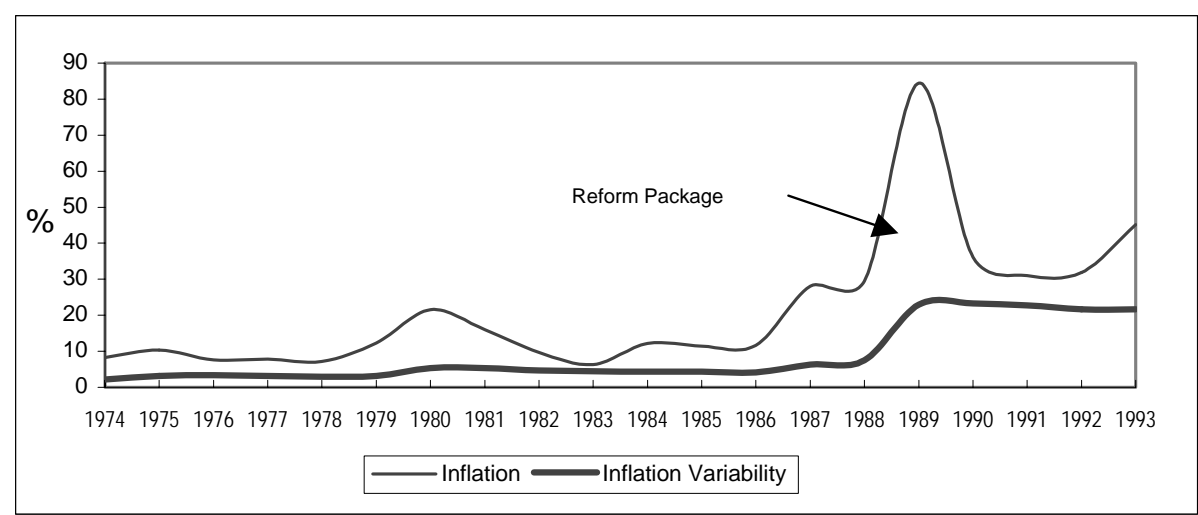

Source: Data from the Venezuelan Central Bank

Note: The measure of inflation variability for each year is the standar desviation of the inflaction rate over the past decade

Fig. 5. Terms of Trade and Oil Prices, 1968-1994

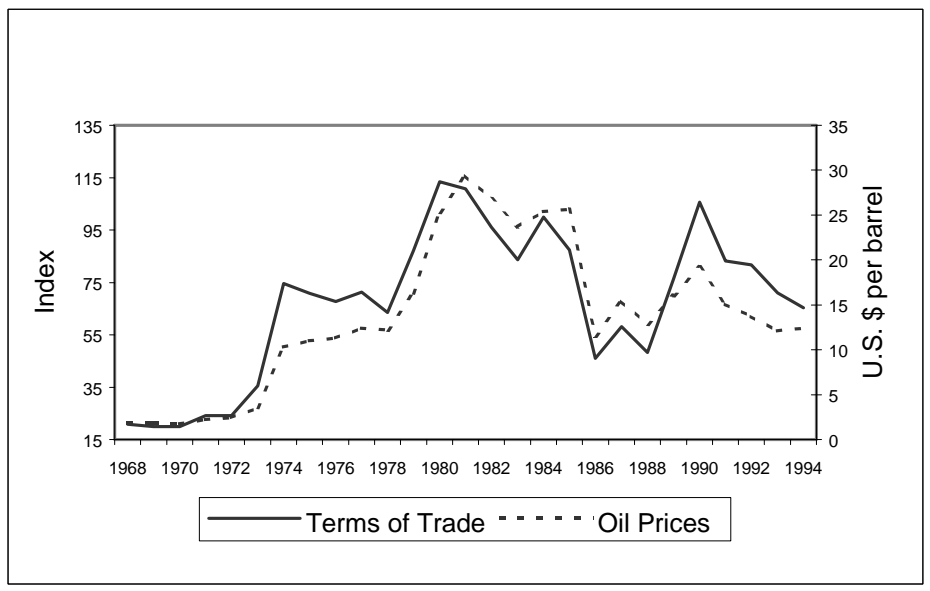

A look to the evolution of private investment (as a percentage of GDP) shows an impressive declined from high 30 percent in 1977 to low 6 percent in the 
preceding year of the banking failure (see figure 6). Though a slight recovery started to take place in 1991-1992 biennium, as a result of oil-driven expansion, the trend represented a worrisome factor that suggested an increased scrapping in productive loans. Since 1988 a close association between private investment/GDP ratio and the intermediation index (as measured by the ratio of loans to deposits) might have started to indicate the importance of the changing macroeconomic context in the explanation of the functioning the of the financial system. From the discussion above, it appears then likely that the macroeconomic environment was to some extent responsible for the fall in investment and the consequent deterioration in financial intermediation which reached its lowest level $(0.57)$ by the end of 1993.

Fig. 6. Venezuela: Private Investiment/GDP Ratio and Intermediation Index, 1969-1994



Source: Data from the Central Bank of Venezuela and the Banking Superintndency

Beyond the evolution and trends of macroeconomic aggregates, a high inflation rate combined with and adverse external shock in the context of absolute capital mobility and relatively fixed exchange rate system may increase the fear of devaluations. If authorities resort increasingly to maintaining a fixed exchange rate policy to contain inflationary pressures, a steady decline in real broad money demand will occur and the economy will experience capital flight. Tight monetary policy increases interest rates sharply and this in turn can lead to adverse selection problems (low risk borrowers are driven from the market) and to a gradual increase in losses from nonperforming loans. 
If we focus on the playing field of the early 1990s in Venezuela the essence of the arguments mentioned above is reaffirmed by the events. The inflation rate remained high at a 31.9 percent in 1992 (and increased to 45.9 percent in 1993). A week oil market reduced the price of oil from an average 19.1 dollars per barrel in 1990 to 13.7 US\$ in 1992. In addition, the two coup attempts in 1992 generated an environment of political uncertainty. Under such conditions, the demand for real broad money declined very early in 1992 (see figure 7). This led to a fall in bank deposits, notwithstanding the high increase in the borrowing interest rates from 31 percent in 1991 to 35 percent in 1992 and 54 percent in 1993 (Garcia et. al. 1998). In fact, deposits fell by about 11 percent in real terms in 1993 with respect to 1991 (Garcia-Herrero 1997). The level of intermediation started to fall in 1992 and the banking system registered an increase in the ratio of nonperfoming loans to total loans from 4 percent in 1991 to 10 percent in 1993 (Garcia-Herrero 1997).

Fig. 7. Venezuela: Quarterly Money Demand (M2/P), 1988-1994

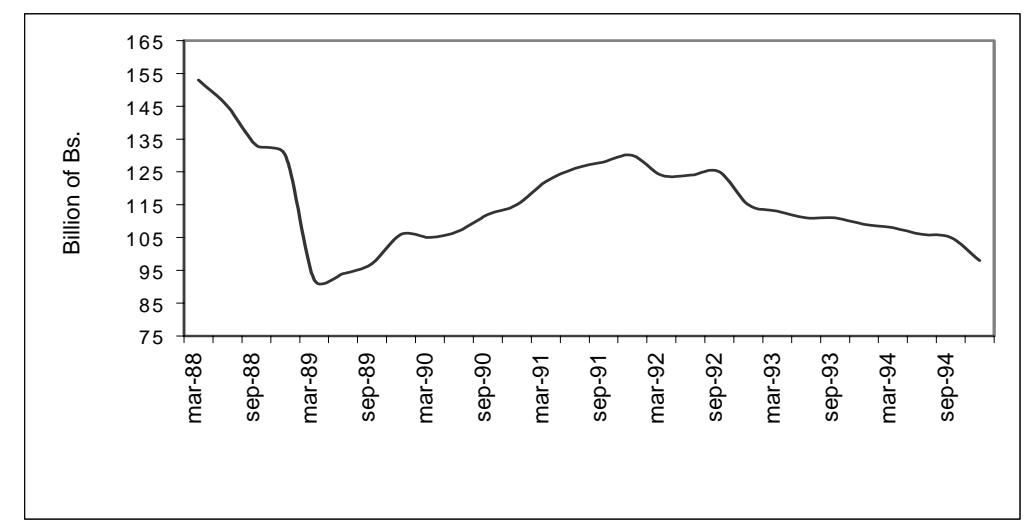

In addition to macroeconomic stability, the level of economic activity does affect adequate credit and deposit flows and uncovered the position of financial units. A recession reduces the internal funds to finance investment or to decrease indebtedness of productive borrowers. With this the burden of repayment rises and likelihood of bankruptcy of both borrowers and banks increases. A recession could also form the basis for pessimistic expectations and lead investors to postpone investment until the recovery arrives; this, in turn, may prevent the take off of the credit market and delay the recovery itself. In the case of Venezuela, although the economy grew at an average rate of 2.8 percent between 1989 and 1993, output growth in the year preceding the crises was negative. The drastic change in the outlook after two failed military coups in 1992, and the Supreme Court decision to deliver political power to the Congress 
in June 1993, left the feeling that too much reforms within relatively short periods of time may not be endurable given the nature of sociopolitical set-up of the country. As we just mentioned with an unrestricted link between the domestic and the international financial markets, large portfolio adjustment occurred affecting the demand for money and bank's liquidity positions (CBV 1993).

\section{THE INSTITUTIONAL SETTING}

Financial institution performance depends crucially of the institutional setting in which it develops. The Venezuelan Banking system was exposed not only to an inadequate supervisory and regulatory framework but also to inadequate incentives.

The Banking Superintendence lacked expertise, qualified human resources and adequate technology to monitor the banks and enforce regulations. Standard accounting practices, risk assessment and classification were not performed effectively. All this reduced the power of the supervisory authorities especially as regards the accuracy of the data reported by banks and the enforcement of existing regulations. Moreover, eclipsed by the tutelage of the Finance Ministry, the Banking Superintendence did not have the power to enforce the law.

Regulations and legislation were also weak in the sense that they allow inadequate capital requirements and inadequate restraints on how financial institutions could invest the funds that were entrusted to them ${ }^{12}$. During the $1980 \mathrm{~s}$ and early 1990s banks did not consolidate their operations in reporting authorities because it was not legally required. This made it difficult to establish limits on lending within financial groups ${ }^{13}$. Financial statements, for instance, did not registered offshore transactions, trading desk operations and other financial transactions that became common by the end of the 1980s. Because of the lack of consolidated supervision, financial groups had clear incentives to divert problem loans or losses to their related affiliates as to avoid limits on bank loan concentration, especially to their off-shore branches since they were not supervised and they were not subject to reserve requirements. In the early 1990s also every bank in the country used to have its own trading desk. Even the Central Bank had its own trading desk as an instrument to control liquidity since 1987. Using their

\footnotetext{
${ }^{12}$ According to Mata (1996), the changes occurred in banking legislation lowered the solvency requirements over the years. Thus, the limits of the liabilities/capital ratio increased from 8 in 1970 to 20 in the 1975 reform. In addition, the reform of 1988 established capital standards in nominal terms (in a country with already high inflation) and no capital adequacy ratio was use as a guideline for prudential supervision.

${ }^{13}$ Progress was made with the approval of new banking legislation in January 1994 . The new legislation introduced consolidated accounting standards for the industry.
} 
trading desk banks were able essentially to attract deposits and make loans without observing even the few regulations that existed in Venezuela at the time.

Moreover, banking operations became practically unique due to the complicated relationships among the banks and the way certain banks manipulated assets both to try to take over other banks and to make their own balance sheets look better. The most notorious example grew out of the battle for Banco de Venezuela. The winner, Banco Consolidado, bled Banco de Venezuela shifting assets and deposits from one to another to salvage Consolidado whose mismanagement and bid for the bank had practically ruined it. The transfer of funds was made through a bank in Curacao in order to avoid detection; a form of kiting that was prevalent throughout the industry.

Incentives for banks not to engage in risk taking were also inadequate. The lack of prudential regulation and supervision in conjunction with the growing importance of financial groups and credit concentration stimulated lending operations to enterprises that the groups already owned or to enterprises with no adequate collateral. The intellectual foundation of the particular legislation that allowed financial groups was undermined by the behavior of banks. Arocha and Rojas (1996) have argued, for instance that specialization within financial groups generated an overexpansion of the banking system and an increase in intermediation costs. In addition, Bello (1986) has observed that the restructuring of banking sector into financial groups shifted the intermediation function of the banking system towards the investor function where the direct acquisition of enterprises (that end up affiliated to the banking matrix) increased the risk of insolvency of the system.

The lack of information regarding the performance and solvency situation of individual banks was an additional problem. The public was virtually impeded to monitor their funds destiny. Moreover, it is well known that a deposit insurance scheme, which is supposed to reduce the probability that the failure of one institution can be spread to other institutions, may reduce private sector monitoring of intermediaries and increase incentives for risk taking (Levine 1996). In the case of Venezuela these moral hazard problems were magnified due to the lack of adequate bank regulation and supervision. The point is that deposit insurance lowers the benefit of maintaining high capital standards to rescue depositors. The banks with access to deposit insurance have incentives to reduce capital/asset ratios. Similarly, banks with insurance deposits have weaker incentives to signal depositors that the bank is maintaining its risk well. Furthermore, banks with deposit insurance have greater incentives to lend to riskier clients. Overall, the combination of greater incentives for banks to assume risk and lower incentives for clients to monitor the behavior of the financial institutions implies that insurance dramatically 
augments the need for compensating government actions. These were virtually absent and not compelled by the Banking Superintendence.

Finally, as we have mentioned the signs given by the Central Bank were not right. The Bank had its own trading desk operations since the late 1980s. Also driving short-term operations through the trading desk was the rapid expansion of the Central Bank securities. As we will comment below, this expansion in large part reflected the increase issuance of zero coupon bonds that to some extent became an important component of bank's portfolio depleting investible resources.

\section{BANKING SYSTEM TRENDS}

The banking system, which had suffered partially the rigors of the economic crisis of the 1980s, still experienced more severe difficulties just before and after the 1989-reform package was implemented.

Table 1 presents some data relevant to an assessment of banking system trends. In the first column is the percentage of financial revenues over commercial banks total revenues. Except for some minor improvement in 1989, following a sharp drop in 1988, the index was on a downward trend. Banks were relying on substantial non-financial revenue to generate overall profits ${ }^{14}$. Indeed the intermediation index as measured by the Central Bank -the ratio of loans to deposits- declined sharply since 1989 (column three). Banks were already involved in a speculative boom that included Central Bank and government securities, trading desk operations, real state, and interbank markets. In fact, official figures indicates the growth rate of bank loans and investments in property shares and much else besides was about 700\% between 1988 and 1994 (the economist, 1995). Moreover, since 1989, changes in the proportion of government and Central Bank securities to loans in the portfolio of commercial banks were dramatic (column four). Of course, a look to the capital/asset ratio (the classic solvency index) did not reveal clearly the trend toward fragile finance even though the index was well below international standards. This index does not take into account a risk weighted sum of assets and off-balance sheet exposure either ${ }^{15}$.

\footnotetext{
${ }^{14}$ Mujica (1995) points out that the low rate of growth of banks' financial revenues between 1987 and 1993 can be attributed to the negative growth rate of productive assets.

${ }^{15}$ In 1988 the Basle Committee established an universal rule where the minimum capitalasset ratio should gravitate around $8 \%$ for the year 1992. However, regarding the issue of capital standards it is important to raise two comments: First, as we mentioned before, the banking Law of 1988 established capital standards in nominal terms and no capital-asset
} 
Table 1. Venezuela: Commercial Banks Selected Indicators, 1985-1993

\begin{tabular}{|c|c|c|c|c|c|}
\hline Year & $\begin{array}{l}\text { Percentage of } \\
\text { Financial } \\
\text { Revenues } \\
(1)\end{array}$ & $\begin{array}{l}\text { Percentage of } \\
\text { Non-financial } \\
\text { Revenues } \\
\text { (2) }\end{array}$ & $\begin{array}{l}\text { Intermediation } \\
\text { Index } \\
\text { (3) }\end{array}$ & $\begin{array}{l}\text { Percentage of } \\
\text { Government } \\
\text { Securities to } \\
\text { Loans } \\
\text { (4) }\end{array}$ & $\begin{array}{c}\text { Capital } \\
\text { Adequacy } \\
\text { Index (5) }\end{array}$ \\
\hline 1985 & $88.51 \%$ & $11.49 \%$ & 0.75 & $12.98 \%$ & $5.2 \%$ \\
\hline 1986 & $91.53 \%$ & $8.37 \%$ & 0.81 & $12.48 \%$ & $5.2 \%$ \\
\hline 1987 & $90.11 \%$ & $9.89 \%$ & 0.89 & $10.07 \%$ & $5.2 \%$ \\
\hline 1988 & $84.81 \%$ & $15.19 \%$ & 0.96 & $6.77 \%$ & $5.5 \%$ \\
\hline 1989 & $87.26 \%$ & $12.74 \%$ & 0.77 & $10.23 \%$ & $5.8 \%$ \\
\hline 1990 & $85.14 \%$ & $14.86 \%$ & 0.57 & $27.64 \%$ & $5.4 \%$ \\
\hline 1991 & $78.34 \%$ & $21.66 \%$ & 0.60 & $21.58 \%$ & $5.4 \%$ \\
\hline 1992 & $75.54 \%$ & $24.46 \%$ & 0.63 & $17.91 \%$ & $6.4 \%$ \\
\hline 1993 & $73.83 \%$ & $26.17 \%$ & 0.57 & $26.84 \%$ & $7.2 \%$ \\
\hline
\end{tabular}

It is clear from above, that in the analysis of financial system trends in Venezuela what matter most is the composition of financial aggregates more than financial aggregates themselves. The figures reveal that the Venezuelan economy had a banking system in which normal functioning depended upon money-market instruments being available for position making. In Minsky's (1986) terminology government and Central Bank securities, for instance, were position-making instruments in the sense that they allowed banks to arrange their assets structure so that they always had assets that could be used to force cash to flow toward them. The problem is that when these instruments are used in position-making, banks substitute one asset (business loans) for another (government and Central Bank securities) ${ }^{16}$.

As a result of the important increase of money-market instruments and the high interest rates, a substitution of checking account deposits for saving and

ratio was used as a guideline for prudential supervision. Second as Garcia, Rodriguez and Salvato (1998) have pointed out, in economies where there is a high degree of money and financial instability, the Basle standards can be insufficient. The Basle criteria has been developed for industrial countries with more stable economies and less sensible to external shocks.

\footnotetext{
${ }^{16}$ We have just argued, however, that the fall of bank lending can also be attributed to the decline in the demand for bank loans due, in part, to the unstable and sluggish macroeconomic environment.
} 
time deposits took place by the end of 1993 (see table 2). In addition, mayor changes occurred in the evolution of lending and cash, and reserves. The high interest rates that prevailed since financial liberalization and the economic recession increase the amount of nonperforming loans and substantially reduce the amount of credit to the private sector. This was reflected in large quantities of excess reserves on banks' balance sheets which were use either to buy central bank and government paper or to increase reserves. In Table 2, which presents a facet of the commercial banks' balance sheets, we may observe how equity investment increased from 5.3 percent of total assets in 1988 to 13.6 percent in 1993. On the other hand, cash and reserves steadily increased from 19.7 percent to 30.1 in 1993.

Table2: Venezuela - Commercial Banks' Balance Shee (as a percentage of total assets)

\begin{tabular}{lrrrrrr}
\hline & 1988 & 1989 & 1990 & 1991 & 1992 & 1993 \\
\hline Assets & 100 & 100 & 100 & 100 & 100 & 100 \\
Cash and Reserves & 19.7 & 24.7 & 26.9 & 3.2 & 30.8 & 30.1 \\
Loans & 59 & 53.9 & 44.6 & 45.1 & 49.7 & 43.6 \\
Equity Investments & 5.3 & 7.0 & 14.2 & 11.6 & 8.9 & 13.6 \\
Fixed Assets & 2.4 & 3.1 & 3.0 & 2.9 & 3.4 & 4.0 \\
Other Assets & 13.1 & 10.7 & 10.8 & 8.6 & 6.5 & 7.5 \\
Liabilities & 94.5 & 94.2 & 94.7 & 94.5 & 93.5 & 92.8 \\
Checking Deposits & 32.3 & 28.3 & 26.7 & 29.5 & 26.1 & 23.5 \\
Saving and Time Deposits & 55.8 & 58.8 & 61.8 & 60.1 & 61.6 & 62.6 \\
Other Liabilities & 6.4 & 7.0 & 6.1 & 4.9 & 5.8 & 6.7 \\
Net Worth & 5.5 & 5.8 & 5.3 & 5.4 & 6.5 & 7.2 \\
\end{tabular}

Source: Garcia, Rodriguez and Salvato (1998)

The marked changes between the time structure deposits surely affected the liquidity position of banks. In fact, we see the high spread between bank's interest on loans and their cost of funds during the previous years to the financial collapse as a way of forcing a cash flow in their favor to make position ${ }^{17}$. Table 3 shows the increase in spreads as the 1994 financial collapse approached. Real interest rates became also positive once financial liberalization was put in place, but they exploded in 1993 once financial disorder was imminent. This recurrent behavior of real interest rates in countries where financial liberalization takes place raises an important question in thinking about the causes of this phenomenon. In reference to the case of Argentina, for instance, Fernandez (1983) describes how banks refrained to change bad assets for losses and

\footnotetext{
${ }^{17}$ Of course, this is not the only explanation for high spreads. High spreads can be the result of high degree of oligopoly power in the provision of bank services or the result of high intermediation costs.
} 
instead preferred to raise interest rates and deposits in order to protect their cash flow.

Table 3: Venezuela - Interest Rates of Commercial Banks (annualized quarterly rates). 1986-1993

\begin{tabular}{|c|c|c|c|c|}
\hline \multirow[b]{2}{*}{ Quarters } & \multicolumn{2}{|c|}{ Nominal Interest Rates } & \multirow[b]{2}{*}{ Spread } & \multirow[b]{2}{*}{ Real Interest Rate } \\
\hline & $\begin{array}{c}\text { Average } \\
\text { Borrowing Rate }\end{array}$ & $\begin{array}{l}\text { Average Lending } \\
\text { Rate }\end{array}$ & & \\
\hline 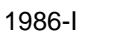 & 8.44 & 13.66 & 5.22 & 3.33 \\
\hline $1986-$ II & 8.41 & 13.75 & 5.34 & 5.20 \\
\hline 1986-III & 8.43 & 13.72 & 5.29 & -16.72 \\
\hline 1986-IV & 8.40 & 13.70 & 5.30 & -21.81 \\
\hline $1987-1$ & 8.36 & 13.62 & 5.26 & -23.98 \\
\hline 1987-II & 8.38 & 13.69 & 5.31 & -15.72 \\
\hline 1987-III & 8.36 & 13.59 & 5.23 & -12.65 \\
\hline 1987-IV & 8.35 & 13.68 & 5.33 & -14.33 \\
\hline 1988-I & 8.30 & 13.62 & 5.32 & -22.81 \\
\hline 1988-II & 8.36 & 13.69 & 5.33 & -49.79 \\
\hline 1988-III & 8.33 & 13.76 & 5.43 & -64.58 \\
\hline 1988-IV & 8.37 & 13.77 & 5.4 & -63.33 \\
\hline I-1989 & 25.31 & 31.99 & 6.68 & -37.32 \\
\hline 1989-II & 39.39 & 44.57 & 5.18 & -3.76 \\
\hline 1989-III & 35.52 & 45.95 & 10.43 & 7.53 \\
\hline 1989-IV & 36.41 & 49.57 & 13.16 & 7.77 \\
\hline I-1990 & 35.33 & 49.62 & 14.29 & 3.79 \\
\hline 1990-II & 25.81 & 38.76 & 12.95 & -5.43 \\
\hline 1990-III & 33.82 & 49.55 & 15.73 & 3.44 \\
\hline 1990-IV & 25.08 & 34.52 & 9.44 & -4.08 \\
\hline |-1991 & 32.24 & 42.62 & 10.38 & 4.90 \\
\hline 1991-II & 34.51 & 46.30 & 11.79 & 6.83 \\
\hline 1991-III & 33.36 & 47.75 & 14.39 & 5.21 \\
\hline 1991-IV & 30.60 & 47.08 & 16.48 & 1.49 \\
\hline I-I992 & 34.49 & 46.51 & 12.02 & 6.49 \\
\hline 1992-II & 36.53 & 50.20 & 13.67 & 6.76 \\
\hline 1992-III & 35.12 & 47.30 & 12.18 & 4.07 \\
\hline 1992-IV & 50.01 & 67.51 & 17.5 & 17.7 \\
\hline I-1993 & 54.10 & 72.38 & 18.28 & 15.67 \\
\hline 1993-II & 60.68 & 85.59 & 24.91 & 21.13 \\
\hline 1993-III & 59.18 & 84.35 & 25.17 & 10.91 \\
\hline 1993-IV & 67.66 & 56.51 & 17.53 & 13.40 \\
\hline
\end{tabular}

Source: Central Bank of Venezuela, Annual Economic Reports and owned calculations

Another complementary hypothesis for explaining the extravagant spread focus on the high intermediation costs that resulted from the constitution of specialized financial institutions and the entrance of new banks after the liberalization attempt. Between 1988 and 1994, when widespread signs of distress and speculation and fraud increased notoriously, regulators authorized the entrance of 15 new banks (which accounted by the year of the crisis about $30 \%$ of the total number of commercial banks). The problem is that lenders are 
likely to be affected by the increased competitive pressures unleashed by financial liberalization. As Grabel (1996) has pointed out, in the context of entrance and new competition a financial institution that does not validate the new speculative activities may face slow growth of its capital base and a loss of market share.Thus, financial institutions are compelled to finance projects that might be unacceptable in a less competitive climate.In the advent of more competition, a lack of experience, of qualified human resources and technology can push the banks towards higher intermediation costs.Figure 8 shows how transformation costs (in real terms) substantially increase since the early 1990.In fact, Garcia et.al. (1998) have pointed out that since 1988 the high transformation costs could not be covered by ordinary financial revenues, a situation that made the operational margin/net worth ratio negative (even in nominal terms).

Fig.8. Comercial Banks'Operational Costs (in real terms)

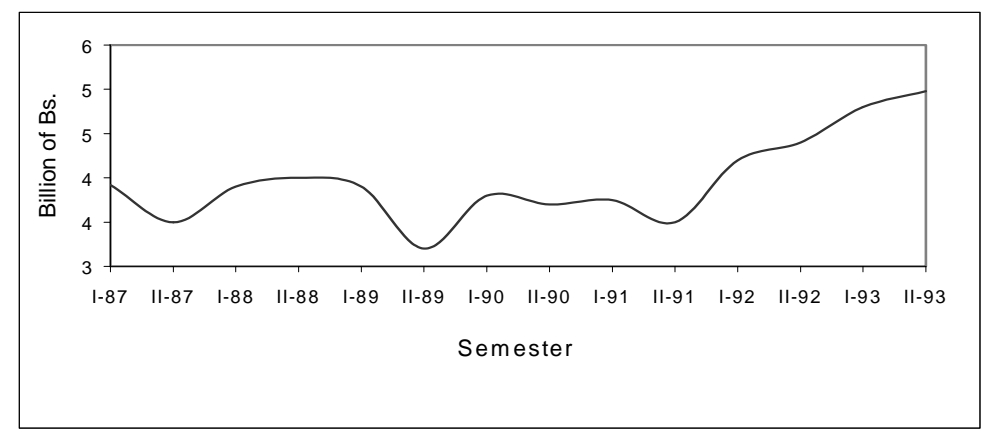

\section{POLICY MALPRACTICE}

We have emphasized concerns over the macroeconomic and institutional context to elucidate the causes and development of the Venezuelan financial crisis. However, policy mistakes as represented by the uncritical proliberalization perspective that prevailed in the country after 1989, precipitated the banking crisis. In 1989 as a result of deregulation, interest rates on loans increased from 14.63 in February to 27.60 in March, and averaged $35.28 \%$ over the year. High interest rates severely weakened the financial position of firms already affected by the recessive bias of the stabilization program. In 1989 the level of nonperforming loans of commercial banks increased 103.9 percent in comparison to 1988 (BCV 1989). High interest rates may also alter the riskiness of the pool of borrowers and banks may react restricting credit (Mankiw 1986), and firms will be unable to finance investment. In the aggregate, reduced investment forces cash 
flow down, limits the ability of firms to service debt, and validates the banker's original decision to tighten credit.

Cash flows and firm's ability to service debt also declined as a consequence of the severe downturn that the Venezuelan economy suffered immediately after the IMF/World Bank program was implemented. Tight monetary and fiscal policy contributed to the downturn. The Central Government fiscal deficit as a proportion of GDP was reduced from $6.1 \%$ in 1988 to $1 \%$ in 1989 as a result of drastic cuts in government spending. In addition, under the advice of IMF staff the Central Bank, in an attempt to restrict liquidity, initiated its open markets operations by the end of $1989^{18}$. In 1989 the economy contracted by as much as $10 \%$. Further, the hostile climate toward reforms and the bloody riots of February 1989 (a tested endogenous response to orthodox packages) provoked attrition within the private sector.

Similar reasoning applies to the trade liberalization and price realignments occurred during the reforms. In reference to the Venezuelan case, Hausmann and Gavin (1995) have pointed out that the 1989 import liberalization and relative price realignments led to severe insolvency in some productive sectors, which in turn had a negative impact in bank's balance sheets. This argument received also close scrutiny in the literature of financial debacles in other Latin American countries.Fernandez(1983), for instance, stresses the role that trade liberalization and exchange rate overvaluation had in the wave of bankruptcies that occurred in Argentina before the financial collapse. Schneider (1985) arrives at quite similar causal relationship for the case of Chile. Accordingly, imports penetration brought about by trade liberalization and exchange rate overvaluation made many firms in the productive sector very fragile with an important part of the loans of financial institutions becoming nonperforming.

During 1990 and in line with the financial reform process, the Central Bank actively used its own securities (the zero coupon bonds) as a mechanism of monetary absorption. In fact, the Central Bank bonds became the fundamental instrument of monetary control since the discount rate was adjust passively to keep in line with market lending rates and reserve requirements were seen only as a way of complementing the absorption of liquidity. But, in August 1990, the Gulf crisis disrupted global oil markets and Venezuela benefits from a favorable external shock. The new oil windfall was monetized and expansionary fiscal policy followed. The country also experienced an euphoric flow of capital into the

\footnotetext{
${ }^{18}$ Mata (1996) refers to the existence of a confidential inform (the Lindgren inform) where the IMF recommended the use of Central Bank securities.
} 
nation's financial markets (common following liberalization). Forced by the expansionary fiscal orientation and the inflows of capital, the Central Bank intensified its restrictive monetary actions by increasing the use of zero coupon bonds. Table 8.4 provides overall figures on the total issuance of zero coupon bonds since the Central Bank begun to issue these instruments in November 1989 until December 1994, a year after the financial crisis exploded.

Table 4:Venezuela - Zero Coupon Bonds, Average Yields and Money Base, 1989-1994 (Million of Bs.)

\begin{tabular}{|c|c|c|c|c|c|}
\hline $\begin{array}{c}\text { iError } \\
\text { ! } \\
\text { Marc } \\
\text { ador } \\
\text { no } \\
\text { defini } \\
\text { do.Ye } \\
\text { ar }\end{array}$ & $\begin{array}{c}\text { Zero Coupon Bonds } \\
\text { (ZCB):Amount } \\
\text { Issued }\end{array}$ & $\begin{array}{c}\text { Average Yield } \\
(\%)\end{array}$ & $\begin{array}{c}\text { Interest Payments } \\
\text { on } Z C B\end{array}$ & $\begin{array}{c}\text { Money } \\
\text { Base }\end{array}$ & $\begin{array}{c}\text { Interest } \\
\text { Payments/Money } \\
\text { Base }\end{array}$ \\
\hline 1989 & 4,390 & 43.82 & 1,924 & 98,560 & 0.01 \\
\hline 1990 & 242,363 & 33.55 & 81,312 & 179,697 & 0.45 \\
\hline 1991 & 571,962 & 34.79 & 198,985 & 330,444 & 0.60 \\
\hline 1992 & 335,069 & 38.82 & 130,073 & 382,310 & 0.34 \\
\hline 1993 & 407,992 & 52.11 & 212,604 & 422,695 & 0.50 \\
\hline 1994 & $2,263,806$ & 47.98 & $1,086,174$ & 698.839 & 1.55 \\
\hline
\end{tabular}

Source: Central Bank of Venezuela, Annual Economic Reports, 1989-1994, and own calculations

The total issuance of zero coupon bonds more than doubled between 1990 and 1991 and the proportion of interest payments to the money base averaged 0.47. As far as the banking system was concerned, the timing could not have been better. Banks became the main beneficiaries of tight monetary policy by shifting very rapidly the composition of their portfolios toward Central Bank bonds. Neither government authorities nor IMF technical staff worried about the consequences that this trend had for the banking industry and the real economy $^{19}$. Questions remained and still remain, however, regarding the consequences of this portfolio shift in banks assets, and regarding the sustainability of this trend.

It is important to note that interest rates depended greatly on the zero coupon bonds interest rate since open market operations practically substituted discount window transactions. It was trough this avenue that interest rate policy was conducted. Therefore, the supply of zero coupon bonds, entirely controlled by the

\footnotetext{
${ }^{19}$ Even after the crisis IMF Technical staff still believed that the continuing shift in the composition of credit toward claims on the public sector reduced default risk (IMF 1996, p. 12).
} 
Central Bank, partially determined the price and yields of bonds and indirectly the high (nominal and real) interest rates that prevailed during 1989-1993. These high interest rates made it difficult for borrowers to repay their typically variablerate loans driving out profitable investment. Problems in the banks did not became visible but motivated speculative activity that weakened the banks further.

\section{THE COLLAPSE AND THE COSTS OF THE CRISES}

President Pérez was finally impeached for misuse of government funds in May 1993. Since then an interim government headed by Ramón Velázquez pay extreme attention to the restoration of the political stability climate virtually lost during Pérez's administration. However, the economic crisis followed on a grand a durable scale. The fall in oil revenues exacerbated the fiscal deficit and promote major inflationary tensions in an environment already plagued of exchange rate instability and uncertainty about the future orientation of economic policy that would follow the presidential elections of 1993. By the end of the year interest rates has risen so high that they not only put borrowers at risk but because interest rate increases push up loan default rates- imperiled lenders as well.

The financial crisis manifest itself in January 1994 when the Board of the Banking Superintendency decided to intervene Banco Latino, by then the country's second-largest bank ${ }^{20}$. Banco Latino depositors started withdrawing their money from the bank as early as October 1993. By the end of 1993 the bank was already engage in a sophisticated Ponzi scheme and a third of the deposits had fled. While interest rates associated with the country's high inflation made other banks offer a $50 \%$ rate, Banco Latino along with other banks were paying $80-100 \%$ on deposits. They just needed to raise their cash flow. The collapse and subsequent closure of the bank led to an extended panic among depositors and to a series of runs on banks whose reputation were highly dubious. Most of these banks had gone into a variety of unorthodox schemes and investments. The avenues included, Venezuelan debt, zero coupon bonds,

\footnotetext{
${ }^{20}$ In 1984 the bank was the country's sixth-largest. After president Pérez appointed Banco Latino Chairman, Pedro Tinoco, as head of the Venezuelan Central Bank, it took off. By the time Banco Latino was in tatters, it had jumped to the number two spot, with full scale branches in Miami, Curacao and Bogota. It was even planning on opening a branch in Paris. Indeed, if the off-balance-sheet items that boosted its losses were included, Banco Latino was actually the nation's largest bank. The bank began to raise its profile as the dominant trader of Venezuelan debt swaps made possible by the 1989 IMF/World Bank agreement.
} 
real state, the stock market as well as direct loans to the front companies connected with them.

The new government that took office in February 1994 had the unenviable task of picking up the pieces left by the banking industry failure. One of the huge problems that the government had to face was that FOGADE (the deposit insurance fund) had a third of its cash deposits at Banco Latino, and Pension Funds for both military and oil industry were housed there as well ${ }^{21}$. All were bailed out.

The strategy of remaining the bank closed for about four months proved to be wrong and costly. Panic was widespread since depositors remained uncertain about their funds destiny. The increasing loss of confidence in the financial system and the lack of a coherent plan to face the crises led to severe monetary disorder. A remarkable fall in the demand for money and an increasing capital flight led to a severe loss of international reserves. There were fears of exchange control, devaluation and partial freezing of bank deposits. Between December1993 and March 1994 (in just three months) international reserves fell by $\$ 2,060$ million. By end-March seven banks and a financial company were virtually excluded from the overnight interbank market. Runs also affected the trading desks and off-shore operations of these banks, especially after it became known that there were large amounts of hidden off-balance sheet deposits and virtually no asset coverage. FOGADE continue to assist these banks without compelling them to adopt a restructuring plan. The government and the Central Bank did not take any action until the end of April when the crawling peg system had collapsed and was replaced by a floating exchange rate regime. A strong devaluation followed the announcement. In May 1994 a foreign exchange auction system replaced the floating system, but the decision to intervene eight important financial institutions introduced additional pressures in the exchange market. Finally, after a huge loss of reserves (about $\$ 3,600$ million), the government decided to put forward an exchange control (by the end of July) ${ }^{22}$.

In early June, the CBV had decided to stop lending to FOGADE and the eight distressed financial institutions with about 21 percent of total deposits had to be interved. With the intervention and control of this eight major financial institutions in June 14, regulatory authorities had to admit publicly that many banks were

\footnotetext{
${ }^{21}$ Even the U.S. embassy had an account at Banco Latino.

${ }^{22}$ In retrospect, it can be stated that the mode and pace of exchange rate reforms progressed in leaps and bounds, mostly following pragmatic on-site solutions to the emerging problems.
} 
distressed and that the crises was of systemic nature ${ }^{23}$. Since January massive sums of money had been needed to keep these banks afloat. In six months both the Central Bank and the FOGADE channeled about $\$ 3,000$ million to these banks. An enormous effort that in practice represented little or no change in the solvency position of distressed banks. The government did not intervened earlier due to the wrong belief that FOGADE had the situation under full control. In reality, the position of FOGADE was extremely weak. In some cases the sum of the rescue operations were well above the amount of deposits, and the estimated losses many times above the net worth of the banks (see Table 5). The fragile institutional framework to deal with the crises led to the creation of the Financial Emergency Board (FEB), a high ranking executive body composed of the minister of finance, the governor of the central bank and three other high ranking officials.

Table 5:Venezuela - Rescue Operations and Estimated Losses of Ditressed Banks of the First and Second Wave, (Million of Bs)

\begin{tabular}{lrrrrrr}
\hline $\begin{array}{l}\text { iError! Marcador no } \\
\text { definido. }\end{array}$ & Deposits & $\begin{array}{l}\text { Rescue } \\
\text { Operations }\end{array}$ & $\begin{array}{l}\text { Rescue } \\
\text { Operation' } \\
\text { S } \\
\text { Deposits }\end{array}$ & Net Worth & $\begin{array}{l}\text { Estimated } \\
\text { Losses }\end{array}$ & $\begin{array}{l}\text { Net Worth' } \\
\text { Estimated } \\
\text { Losses }\end{array}$ \\
\hline Banco Latino & 144,928 & 280,000 & 1.93 & 10,315 & 131,000 & 12.7 \\
Banco de Maracaibo & 121,417 & 98,900 & 0.81 & 10,481 & 75,567 & 7.2 \\
Banco Construccion & 51,332 & 85,550 & 1.66 & 5,127 & 74,000 & 14.4 \\
Banco La Guaira & 27,781 & 41,120 & 1.48 & 4,402 & 33,000 & 7.5 \\
Banco Metropolitano & 52,887 & 83,050 & 1.57 & 4,598 & 78,904 & 17.2 \\
Bancor & 23,053 & 16,975 & 0.73 & 1,963 & 8,607 & 4.4 \\
Banco Barinas & 18,570 & 22,110 & 1.19 & 1,253 & 15,747 & 12.6 \\
Banco Amazonas & 4,337 & 2,120 & 0.48 & 658 & 1,029 & 1.6 \\
Total & 44,306 & 629,825 & 1.41 & 38,797 & 417,856 & 10.8 \\
\hline
\end{tabular}

Source: Veneconomia (1994), Vol. 11, No. 4

The Emergency Board started to work in a situation were no integral diagnosis of the crises existed, no study of the solvency and liquidity positions of the remaining banks had been made, and no consolidated balance sheets of the financial institutions existed. Moreover, the authorities' frequently contradictory statements regarding the health of the banking system and the lack of a comprehensive and consistent policy to deal with bank problems undermined the impact of official actions on public opinions.

\footnotetext{
${ }^{23}$ Among the institutions affected by this second wave of failures and intervened in June were 7 commercial banks: Banco Barinas, Banco Amazonas, Bancor, Banco La Guaira, Banco de Maracaibo, Banco Costruccion, Banco Metropolitano; and a financial society: Fiveca.
} 
Problems in other banks became visible very rapidly. In July the FEB discovered that three more banks were in a fragile position (Banco de Venezuela, Banco Consolidado and Banco Andino). The FEB decided not to rescue these banks but to remove their board of directors and intervened directly. In August, Banco de Venezuela came under State control. Later additions were

Banco Consolidado in September, and Banco Progreso and Banco Republica in December. Three more banks were closed down in February 1995: Banco Principal, Banco Italo and Banco Profesional. Later on, in August 1995, Banco Empresarial was intervened. The deposits held at closed banks were shifted to nationalized banks. However, there were delays in supplying the recipient banks with counterpart earning assets and FOGADE provided the banks with bonds amounting to about 80 percent of the deposits transferred only in December 1995.

The cost of the Venezuelan banking collapsed was spectacular. Between January 1994 and August 199517 financial institutions failed. These institutions amounted 60 percent of the assets of the financial system and more than 50 percent of the deposits. Conservative figures by the Central Bank estimated in U.S. \$ 4,700 million the amount of financial assistance to the banks (Casas 1996), about $9.24 \%$ of GDP. IMF figures indicate that the overall assistance to banks amounted to 13 percent of GDP in 1994 and 4 percent of GDP in 1995. But careful estimations by Garcia et. al. (1998) indicate that the assistance provided by the authorities to banks in difficulty, either directly or through FOGADE, amounted $20 \%$ of GDP. Indirect costs mounted in the form of rapidly growing interest payments arising from the steep increase in domestic debt issued to fund the transfers to banks. By the end of June 1995 the increase in total indebtedness of FOGADE with the Central Bank had amounted nearly Bs. 1.2 billion (18\% of GDP). Central Bank losses increase due to the sharp increase in open market operations to restrict liquidity.

Table 6. Venezuela:

Selected Indicators Before and During the Financial Crisis

\begin{tabular}{lrrrrrrrr}
\hline & 1988 & 1989 & 1990 & 1991 & 1992 & 1993 & 1994 & 1995 \\
\hline GDP (growth rate) & 5.8 & -8.6 & 6.5 & 9.7 & 6.1 & 0.3 & -2.8 & 2.2 \\
$\quad$ Oil Sector & 8.3 & -0.3 & 13.9 & 10.2 & -1.2 & 7.1 & 4.6 & 6.0 \\
$\quad$ Non-oil Sector & 5.7 & -9.4 & 4.6 & 8.5 & 8.1 & -1.5 & -4.9 & 1.0 \\
Inflation Rate (based on CPI) & 29.4 & 84.4 & 40.6 & 34.2 & 31.9 & 45.9 & 70.8 & 56.6 \\
Overall Public Sector Balance $^{\text {(\% of GDP) }}$ & -11.9 & -1.3 & -0.5 & 0.6 & -5.8 & -2.4 & -14.1 & -6.0 \\
Gross Domestic Investment $^{1}$ & 21.4 & 11.1 & 9.6 & 15.8 & 23.7 & 18.8 & 13.2 & 15.9 \\
\hline
\end{tabular}




\begin{tabular}{lrrrrrrrr}
\hline (\% of GDP) & & & & & & & \\
$\quad$ Private Sector & 12.5 & 3.1 & -0.1 & 5.5 & 8.9 & 8.5 & 6.6 & 5.9 \\
$\quad$ Public Sector & 8.9 & 7.9 & 9.7 & 10.2 & 12.2 & 10.8 & 9.2 & 9.3 \\
$\quad$ Change in Inventories & 4.0 & -3.0 & -2.8 & 0.3 & 2.0 & -0.4 & -2.5 & 1.8 \\
Unemployment Rate & 8.3 & 9.5 & 9.8 & 8.7 & 7.8 & 6.7 & 8.7 & 10.3 \\
Overall Balance of Payments & 7.8 & -3.1 & -2.8 & 0.3 & $-1,2$ & $-0,5$ & $-1,4$ & -1.1 \\
(in billions of US dollars) & & & & & & & & \\
\hline
\end{tabular}

Excluding revenue from Privatization

Source: Central Bank of Venezuela, Central Budget Office, and Ministry of Finance

Time after the crises started, the financial system sharply restricted its credit activity. The intermediation index reduced from $57.8 \%$ in 1993 to $36.9 \%$ in 1994. As government assistance to ailing banks mounted during the year, the fiscal deficit ballooned. In fact, the overall public sector deficit increased to 14.1 percent of GDP in 1994. Table 8.6 shows us how macroeconomic performance was affected as the crises unfold. For the year 1994 as a whole, inflation rose to 70 percent (from 46 percent in 1993), GDP fell by 2.8 percent, gross domestic investment as a percentage of GDP fell from 18.8 in 1993 to 13.2 in 1994 and the unemployment rate increased from 6.7 percent in 1993 to 8.7 in 1994.

\section{CONCLUSIONS}

The Venezuelan financial system was able to sustain its development relatively well in spite of the climate of financial repression, lack of foreign competition and government direct intervention in financial intermediation that prevailed during the late 1960s and 1970s. Banks adaptability to the changing external conditions and the growing economic disarray was characteristic of the 1980s, but by 1988 symptoms of vulnerability already existed. There is some truth in the explanation of the financial crisis as a failure of prudential regulation and institutional incentives. In fact, this is the case of Venezuela. But the role played by macroeconomic factors can not be denied. In this respect we have argued that the degree of uncertainty has a strong impact on the credit market and that uncertainty in developing countries, as in the case of Venezuela, is not only driven by the political turmoil but by key macroeconomic elements; namely: inflation variability and external shocks. In addition, the recessive trend of the Venezuelan economy may have increased non-performing loans and the demand for credit by reducing profitability and inducing pessimistic expectations.

The best example of how policy malpractice may precipitate a financial crash can be found in the process of economic reforms that took shape in Venezuela after 1989. We have showed how conflicts may arise between different aspects of the reforms programs. The liberalization of interest rates affects negatively the financial structures of the economy because it increases cash commitments relative to cash receipts and influences lenders to restrict credit. Speculation 
goes together with deteriorating balance sheets to pave the way for a crash. Evidence shows that banks developed a wide variety of money market instruments to make position and that non-financial revenues as a proportion of total revenues increased dangerously. Tight monetary and fiscal policy may affect negatively intermediation by aggravating the downturn. Moreover, if tight monetary policy is conducted trough open market operations, as in the case of Venezuela, banks may substitute productive investment loans for government and Central Bank securities. In sum, savings flows have no natural outlet into capital formation. The situation worsens if expansionary fiscal policy follows the downturn and if the Bank insists in restrict liquidity by using its own bonds. Finally, as showed by the southern cone experience, trade liberalization and price realignment impact negatively bank's balance sheet if some productive sectors become insolvent.

With due care to avoid facile country comparisons, the situation and the events leading up to the financial crisis in Venezuela and other Latin American countries make an interesting case of study where similarities are more than casual. In these countries the structural conformation of the financial system was fostered by a state-base model of accumulation and strict government intervention. All these countries found themselves in delicate transitions toward reform. They carried out a process of reforms in an unstable macroeconomic context, and the financial deregulation was initiated in an environment of poor prudential regulation and supervision. In that sense Latin American financial crisis experiences illustrate the problem of pursuing reform without sufficient attention to macroeconomic and institutional variables. Financial liberalization led participants to focus on speculation and fraud rather than conventional intermediation. At the end the costs of the crises have been imponderable and the taxpayers have ended up with bills totaling tens of percent of GDP to put the financial system back together.

\section{APPENDIX: RECESION, HIGH INTEREST RATES AND INSTABILITY}

This appendix derives a linkage between a fall in economic activity and the explosive behavior of interest rates. We will also show, within the context of a simple equilibrium framework with credit and goods markets, how high interest rates when combined with low output levels can lead the economy towards an unstable path. In order to make the presentation simple, we will assume that the price level is constant and normalized to unit. Hence no distinction can be made between nominal and real variables. Consider then a Kalecki-Steindl investment function as reproduced by Dutt (1990).

$$
I=\beta_{0}+\beta_{1} r
$$


where private investment, $I$, is sensitive to autonomous changes guided by unexpected and unpredictable events, and by changes in the effective profit rate, $r$.

If market imperfections prevail in the goods market and the mark-up remains constant, following Taylor (1983), the profit rate will respond to changes in the level of economic activity according to the following equation

$$
r=\frac{\tau}{(1+\tau)} \frac{Y}{K}
$$

where $\tau$ represents the mark-up on unit costs, $K$ is the given stock of capital, and $Y$ represents the output level of the economy. We may call $\phi$ the average variable costs, and $p$ the price level of the economy, then we may obtain $r$ by substituting a price level equation $p=(1+\tau) \phi$ into the profit rate equation $r=(p Y$ $\phi Y / p K$.

At the firm level the demand for loans, $L$, equals the sum of corporate debt inherited from the past and the financing gap. We implicitly assume away the amount financed by internal funds.

$$
L_{\mathrm{t}}=L_{\mathrm{t}-1}+I_{\mathrm{t}}
$$

From the balance sheet of the financial system we know that

$$
E=L+Q-R
$$

that is, net worth, $E$, is equal to assets (credits, $L$, and reserves, $Q$ ) minus liabilities, $R$. If for simplicity we assume that the required reserve ratio and excess reserves are zero, then the change in net worth over time $d E / d t$ gives

$$
\frac{d E}{d t}=i L-i_{R} R
$$

where $i$ and $i_{R}$ are the rate that banks charge for loans and the weighted deposit rate, respectively.

Proposition 1. If banks react to a fall in the return on assets by increasing the deposit rate, then the increase in the deposit rate will in turn increase the cash flow needs of the banks and the system will exhibit an unstable and explosive path. 
Proof of Proposition 1. Suppose that the demand for deposits depends positively on the deposit interest rate as shown in expression (6).

$$
R=R\left(i_{R}\right) ; \quad \frac{d R}{d i_{R}}>0
$$

Then a change in the liability side of the balance sheet should be associated with a change in the deposit rate. In that case the time variation of net worth is given by

$$
\frac{d E}{d t}=-\frac{d R}{d i_{R}} \frac{d i_{r}}{d t}
$$

Combining (7) and (5) we may obtain the time path of the deposit interest rate as

$$
\frac{d i_{R}}{d t}=\frac{-i L+i_{R} R}{\left(d R / d i_{R}\right)}
$$

Substituting now (2) into (1) and the result into (3) we get

$$
L=L_{t-1}+\beta_{0}+\beta_{1} \frac{\tau Y}{(1+\tau) K}
$$

which indicates that the demand for loans will depend on the output level of the economy. Substituitng (9) into (8) the time path of the deposit rate yields

$$
\frac{d i_{R}}{d t}=\frac{-\left[L_{t-1}+\beta_{0}+\beta_{1} \frac{\tau Y}{(1+\tau) K}\right]}{\left(d R / d i_{R}\right)}+\frac{R i_{R}}{\left(d R / d i_{R}\right)}
$$

(10) is a first order linear differential equation. The positive sign of $d R / d i_{R}$ makes for dynamic instability and the time path will diverge from equilibrium.

Let us assume now that the bank chooses a deposit rate, and individuals then choose a level of deposits equivalent to the supply of loanable loans. Consequently, the credit market supply of loanable loans can be expressed as 


$$
\begin{aligned}
& R=L \\
& \delta(I) Y=L(Y) ; \\
& 0<\delta<1 ; d \delta / d i>0 ; d L / d Y>0
\end{aligned}
$$

We should point out some additional assumptions in $\left(11^{\mathrm{a}}\right)$ : (a) the supply of loanable funds is a function of income (as a proxy of wealth), (b) by increasing the proportion of income that goes to saving, the relation between the supply of loanable funds and the interest rate is positive and (c) the demand for loans increases with higher income (as we assumed previously).

In the goods market (following Balanchard and Fischer 1989) we assume that adjustment of output to movements in demand takes time. Namely, we assume that

$$
\begin{aligned}
& \frac{d Y}{d t}=\varphi(Y, i) \\
& \varphi_{Y}<0 \text { y } \varphi_{1}<0
\end{aligned}
$$

Note that $\varphi_{Y}<0$ follows from the assumption that the marginal propensity to absorb is lower that one, and $\varphi_{1}<0$ represents the contractionary effect of higher interest rates brought about by higher cost of financing working capital and investment (we do not follow the conventional assumption that higher interest rates reduces investment).

The goods market and credit market equilibrium allow the following proposition:

Proposition 2. The dynamic behavior (over time) of the system that represents equilibrium in both markets yields a saddle point.

Proof of Proposition 2. By differentiating $\left(11^{\mathrm{a}}\right)$ with respect to time we obtain

$$
\frac{d \delta}{d i} \frac{d i}{d t} Y+\frac{d Y}{d t} \delta(i)=\frac{d L}{d Y} \frac{d Y}{d t}
$$

and rearranging 


$$
\frac{d i}{d t}=\frac{[d L / d Y-\delta(i)] d Y / d t}{(d \delta / d i) Y}
$$

Equations (12) y (14) represent a first order differential equation system in the variables interest rate, $i$, and income, $Y$. In steady state conditions, $d Y / d t=0$ $y d i / d t=0$. Moreover, the rule of the implicit function gives us a modified equation (12)

$$
\frac{d i}{d Y}_{\frac{d Y}{d t}=0}=-\frac{\varphi_{Y}}{\varphi_{i}}<0
$$

which indicate that the equilibrium in the goods market will exhibited a downward sloping schedule in the $i-Y$ space. From the $d i / d t=0$ locus in (14) is relatively easy to determine a vertical equilibrium function in the credit market (in the $i-Y$ space). Figure 9 shows the two loci on which $i$ and $Y$, respectively, are not changing.

Fig.9. Phase Diagram

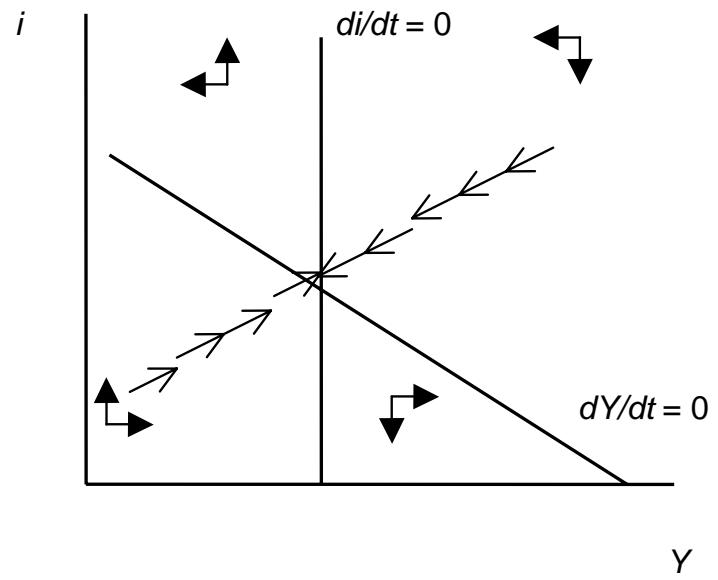

The system is stable in some directions and unstable in others (it yields a saddle point equilibrium). Initial positions that show very high interest rates (above equilibrium) combined with very low income levels (below the equilibrium level) will exhibit instability. 


\section{BIBLIOGRAPHY REFERENCE}

Arocha, M. and E. Rojas (1996), "La Crisis Bancaria en Venezuela: Antecedentes, Desarrollo e Implicaciones", Monetaria, Vol. 19, No. 2.

Bernanke, B. (1983), "Irreversibility, Uncertainty, and Cyclical Investment", Quarterly Journal_of Economics, Vol. 98, No. 4.

Casas, A. (1996), "Experiencia Venezolana en el Manejo de la Crisis Financiera", Revista BCV, Vol. 10, Caracas.

Central Bank of Venezuela (1994) Annual Economic Report, CBV, Caracas.

- (1993) Annual Economic Report, CBV, Caracas.

- (1992) Annual Economic Report, CBV, Caracas.

- (1991) Annual Economic Report, CBV, Caracas.

- (1990) Annual Economic Report, CBV, Caracas.

- (1989) Annual Economic Report, CBV, Caracas.

- (1988) Annual Economic Report, CBV, Caracas.

Dermiguc-Kunt, A. and E. Detragiache (1998), Financial Liberalization and Financial Fragility, presented at the April 1998 Annual Bank Conference on Development Economics, The World Bank.

Diaz-Alejandro, C. (1985), "Good-bye Financial Repression, Hello Financial Crash", Journal_of Development Economics, Vol. 19.

—_El Banco Latino Sale A Flote" (1994), VenEconomia, Vol. 11, No. 4.

Fernandez, R. (1983), "La Crisis Financiera Argentina: 1980-1982", Desarrollo Económico, Vol. 23, No. 89.

Garcia, G., Rodriguez, R. and S. Salvato (1998), Lecciones de la Crisis bancaria en Venezuela, Ediciones IESA, Caracas.

García-Herrero, A. (1997), Banking Crisis in Latin America in the 1990s: Lessons from Argentina, Paraguay, and Venezuela, IMF Working Paper, WP/97/140, Washington, D.C.

Grabel, I. (1996), "Financial Markets and the State and Economic Development", International Papers in Political Economy, Vol. 3, No. 1. 
Hausmann, R. (1990), Shocks Externos y Ajuste Macroeconomico, Banco Central de Venezuela, Caracas.

Hausmann, R. and M. Gavin (1995), The Roots of the Banking Crises: The Macroeconomic Context, (Washington: Inter-American Development Bank).

Held, G. (1992), Desarrollo del Sector Financiero, Liberalización y Complementación Financiera, Mimeo.

International Monetary Fund (1996), Venezuela: Recent Economic Developments, Country Report No. 96/87, IMF, Washington, D.C.

Levine, R. (1996), "Financial Sector Policies: Analytical Framework and Research Agenda", in Niels, H. And R. Lensink, Financial Development and Economic Growth, London: Routledge.

Lewis, P. and H. Stein (1997), "Shifting Fortunes: The Political Economy of Financial Liberalization in Nigeria", World Development, Vol. 25, No. 1.

Mankiw, G. (1986), "The Allocation of Credit and Financial Collapse", Quarterly Journal of Economics, Vol. Cl, No. 3.

Mata, L. (1996), "Banca y Crisis Economica en Venezuela", Nueva Economía, Vol. 5, No. 6.

McKinnon, R. (1993), The Order of Financial Liberalization, Baltimore: John Hopkins Press.

-(1989), "Macroeconomic Instability and Moral Hazard in Banking in a Liberalizing Economy", in Brock, P., Connolly, M. and Gonzalez-Vega, C. (eds) Latin_American Debt and Adjustment, New York: Praeger.

Minsky, H. (1986) Stabilizing an Unstable Economy, Yale University Press, New Haven.

Mujica, A. (1995), "Liberalización Financiera y Crisis Bancaria", Revista de Ciencias Sociales, Vol. 1, No. 2.

Pindyck, R. (1991), "Irreversibility, Uncertainty, and Investment", Journal of Economic Literature, Vol. 29, No. 3.

Schneider, A. (1985), "La Crisis Financiera Chilena", Trimestre Económico, No. 208.

Stiglitz, J. (1998), Sound Finance and Sustainnable Development, Mimeo, The World Bank.

—_Venezuelan Banks: From bad to worse" (1995), The Economist, March 25. 
Zambrano, L., Riutfort, M, Muñoz, R. and J.C. Guevara (1996), "Elasticidad Sustitución, Términos de Intercambio y Restricciones de Liquidez en Venezuela", Revista BCV, Vol. 10. 